\title{
CESARZ JÓZEF II W PARYŻU I WERSALU W 1777 ROKU
}

\author{
Rafał Niedziela \\ Uniwersytet Jagielloński w Krakowie
}

\section{ABSTRACT \\ EMPEROR JOSEPH II IN PARIS AND VERSAILLES IN 1777}

The article describes selected aspects of Emperor Joseph II's stay in Paris and Versailles in 1777. The journey of this ruler to France under the assumed title of Count Falkenstein received a wide coverage in contemporary sources. His curiosity and openness, and above all modest lifestyle, earned him great affection of the French capital inhabitants. He also earned the lasting gratitude of Louis XVI and Marie Antoinette, because he contributed to the improvement of their mutual relation. In Paris he met a number of prominent figures of French politics, culture and science, perseveringly looking for patterns that could be used later in the Habsburg monarchy.

Key words: Joseph II, Marie Antoinette, Louis XVI, France, Paris, Versailles, journeys.

Słowa kluczowe: Józef II, Maria Antonina, Ludwik XVI, Francja, Paryż, Wersal, podróże.

Mogłoby się wydawać, że o podróży Józefa II do Francji w 1777 roku wiemy już niemal wszystko. Poświęcono jej przecież sporo miejsca w artykułach naukowych ${ }^{1}$, wspomina się o niej w biografiach cesarza ${ }^{2}$ i francuskiej pary królewskiej ${ }^{3}$, a także

1 V. Barth, Les visites incognito à la cour des Bourbons au XVIII siècle, trad. de l'allemand par J.L. Muller [w:] Voyageurs étrangers à la cour de France 1589-1789 : regards croisés, sous la direction de C. Zum Kolk, J. Boutier, B. Klesmann et F. Moureau, Rennes-Versailles 2014, s. 323-335; H. Reinalter, Die Frankreichreise Josephs II. 1777 [w:] ,,Voyages... Voyages... ” Hommages à Alain Ruiz, Textes réunis par F. Knopper et J. Mondot, Pessac 2010, s. 53-60; Ch. de Larivière, L'empereur Joseph II à Paris en 1777 et en 1781, „Revue Politique et Parlementaire”, R. 8, avril-juin 1901, t. 28, s. 605-631; J.H. Schnitzler, Le premier voyage de l'empereur Joseph II à la cour de Marie-Antoinette, en 1777, „Revue des cours littéraires de la France et de l'étranger”, R. 3, 26 mai 1866, nr 26, s. 429-436.

2 Zob. m.in. F. Fejtö, Józef II Habsburg rewolucjonista, tłum. A. Kołodziej, Warszawa 1993, s 161-168; K. Gutkas, Kaiser Joseph II. Eine Biographie, Wien-Darmstadt 1989, s. 167-177.

3 É. Lever, Louis XVI, Nouvelle édition, Paris 2014, s. 287-292; eadem, C'était Marie-Antoinette, Paris 2010, s. 164-177; J.-Ch. Petitfils, Louis XVI, t. I : 1754-1786, Paris 2010, s. 312-314; A. Fraser, 
w pracach dotyczących kultury i życia dworskiego ${ }^{4}$. Większość publikacji na ten temat ma jednak ogólny charakter, w większości są one obcojęzyczne, w niektórych przypadkach trudno dostępne dla polskiego czytelnika, a ponadto oparte na szczupłej podstawie źródłowej. Niniejszy artykuł także nie może pretendować do wyczerpania tematu, ze względu na fakt, że eskapadę cesarza obszernie komentowano na kartach okolicznościowych diariuszy, wspominano o niej w korespondencji dyplomatycznej, w pamiętnikach oraz w prasie, a i sam Józef na gorąco dzielił się wrażeniami z pobytu we Francji, pisując do swego brata Leopolda (wielkiego księcia Toskanii) ${ }^{5}$. Z uwagi na ograniczone ramy artykułu nie mogłem zrelacjonować całej czteromiesięcznej podróży, ograniczyłem się więc do ukazania najważniejszych aspektów wizyty cesarza w Paryżu i Wersalu na podstawie wybranych źródeł i opracowań. W stolicy i na dworze królewskim Józef II spędził łącznie sześć tygodni (od 18 kwietnia do 31 maja 1777 r.) i był to kulminacyjny punkt jego wyprawy. Po opuszczeniu Paryża zwiedził jeszcze różne miejscowości północnej, zachodniej i południowej Francji, by wreszcie przez kantony szwajcarskie powrócić do rodzinnej Austrii. Choć trudno deprecjonować walory poznawcze tego ostatniego etapu podróży, dla samego Józefa nie miał on już tak wielkiego znaczenia, toteż w niniejszych rozważaniach zostanie pominięty ${ }^{6}$.

Nie wiemy, kiedy dokładnie cesarz podjął decyzję o złożeniu wizyty we Francji ${ }^{7}$. W liście do Leopolda z 29 października 1776 roku napisał, że myślał o tym już wielokrotnie, ale dotąd nie udało mu się zrealizować tych planów. Zakładał jednak, że nastąpi to w najbliższym czasie. Optymistycznie przewidywał, iż być może dotrze do Paryża na ostatni tydzień najbliższego karnawału. Jednocześnie prosił brata o dyskrecję w kwestii wyjazdu, bo jak stwierdził, na dworze „nikt jeszcze nic o tym nie wie"». Mylił się jednak - Maria Teresa wiedziała już o jego planach, choćby dlatego, że pogłoski na ich temat krążyły od dłuższego czasu po ulicach Wiednia. Oficjalnie syn poinformował ją dopiero w listopadzie, ale bynajmniej nie zamierzała go powstrzymywać ani zniechęcać. Podróż taka była jej nawet na rękę, gdyż na dwór wiedeński

Maria Antonina. Podróż przez życie, tłum. I. Stąpor, Warszawa 2006, s. 199 i n.; J. Baszkiewicz, Ludwik XVI, Wrocław 1983, s. 83-85.

4 L. Bély, La société des princes XVI $-X V I I I^{e}$ siècle, Paris 1999. Zob. J. Ryba, Kamuflaże oświeconych: ,incognito” [w:] Uwodzicielskie oblicza oświecenia. Szkice obyczajowe II, Katowice 2002, s. 70-81.

5 Autorami wartościowych diariuszy podróży cesarza byli m.in. pisarz i dziennikarz Alexandre-Jacques du Coudray, wydawca i poligraf Charles-Joseph de Mayer, duchowny i intelektualista z Niderlandów Austriackich abbé Duval-Pyrau oraz bliżej nieznany (lub podpisujący się pseudonimem) Gauthier de Simpré.

${ }^{6}$ O dalszym etapie podróży m.in. A. Henwo od, L'empereur Joseph II à la découverte de la marine et de la France de l'Ouest (juin 1777), „Annales de Bretagne et des pays de l'Ouest” 1984, vol. 91, nr 4, s. 351-368.

Gdy Maria Antonina opuszczała Wiedeń w 1770 r. i udawała się do Wersalu, obiecał jej, że ją tam odwiedzi, ale być może chciał tylko pocieszyć siostrę, dla której wyjazd z rodzinnej Austrii był traumatycznym przeżyciem. Zob. P. de Ségur, Au couchant de la monarchie. Louis XVI et Turgot 17741776. Louis XVI et Necker 1776-1781, préf. de L. P faadt, Paris 2013, s. 209.

8 Józef II do Leopolda Habsburga, b.m., 29 października 1776 [w:] Maria Theresia und Joseph II. Ihre Correspondenz sammt Briefen Joseph's an seinen Bruder Leopold, Band 2, hsg. von A.R. von Arneth, Wien 1867, s. 122-123. 
zaczęły napływać w tym czasie doniesienia o długach, lekkomyślności i ekstrawagancji Marii Antoniny. Cesarzową bardzo też niepokoił fakt, że po sześciu latach od ślubu związek jej córki z Ludwikiem XVI nie był jeszcze skonsumowany i nic nie wskazywało na to, by w bliskiej przyszłości para miała się doczekać następcy tronu. Bezdzietność Marii Antoniny stawiała pod znakiem zapytania wartość aliansu austriacko-francuskiego. Wywoływała też niezdrowe zainteresowanie w Turynie, na dworze króla Sardynii Wiktora Amadeusza III, otwierała bowiem perspektywy sukcesji przed dwoma zięciami tego władcy (kolejno Ludwikiem hrabią Prowansji i Karolem hrabią Artois) 9 .

Józef miał się zatem udać do Francji przede wszystkim w charakterze psychologa. Pragnął na miejscu dowiedzieć się, dlaczego Ludwik XVI i Maria Antonina nie podejmują starań o potomstwo, a przy okazji chciał poznać swego królewskiego szwagra i jego rodzinę oraz odnowić relacje z siostrą, której nie widział od kilku lat. Zamierzał przywołać Marię Antoninę do porządku, nakłonić ją do przykładnego wypełniania obowiązków królowej i porzucenia niestosownych rozrywek, kładących się cieniem na jej wizerunku. Na pewno też wierzył, że uda mu się zatrzeć złe wrażenie, jakie pozostawił w Wersalu i Paryżu jego brat, arcyksiążę Maksymilian. Podczas wizyty w 1775 roku zachowywał się on niczym słoń w składzie porcelany i popełnił tyle gaf i niezręczności, że Francuzi obdarzyli go przezwiskiem ,arcyzwierz” (archibête). Szczególnie dobrze zapamiętali despekt, jaki spotkał przyrodnika Georges'a-Louisa de Buffona: Maksymilian miał odmówić przyjęcia od niego książki w prezencie, bo jak stwierdził, nie wypada mu pozbawiać autora jego własnego dzieła ${ }^{10}$. Biorąc pod uwagę fakt, że i Maria Antonina miała na swym koncie wpadki wynikające z lekceważenia etykiety, Józef musiał wystąpić w pewnym sensie w obronie honoru dynastii habsbursko-lotaryńskiej. Zależało mu na udanym przebiegu wizyty, tym bardziej że w obliczu spodziewanego wkrótce wybuchu wojny o sukcesję bawarską liczył na dyplomatyczne, a nawet militarne poparcie Francji. Ten stricte polityczny wątek francuskiej podróży był dla niego niezwykle istotny, choć ze względów taktycznych skrzętnie ukrywany. Oficjalnym powodem podróży były sprawy rodzinne i chęć poznania kraju oraz jego stolicy. Cesarz chciał się przekonać, w jaki sposób funkcjonują rząd, administracja, system finansowy, armia, sądownictwo oraz instytucje kulturalne i naukowe we Francji. Celem samym w sobie było dla niego poznanie Paryża. Spodziewał się, że właśnie tu, w Mieście Świateł, spotka wielu ciekawych ludzi oraz znajdzie wzorce do naśladowania i wykorzystania w monarchii habsburskiej, gdy wreszcie obejmie w niej samodzielne rządy ${ }^{11}$.

$\mathrm{Na}$ dworze wersalskim zapowiedź przyjazdu cesarza przyjęto raczej chłodno. Ludwik XVI lękał się jego dociekliwości i krępujących pytań o pożycie intymne. Maria Antonina co prawda szczerze pragnęła go zobaczyć, ale bała się przy tym, że zostanie

9 J.-Ch. Petitfils, op. cit., s. 311.

10 A. Fraser, op. cit., s. 175-176.

11 L. Bély, op. cit., s. 511-515; J.-Ch. Petitfils, op. cit., s. 312; F. Fejtö, op. cit., s. 159. Józef II został cesarzem po śmierci ojca w 1765 r., ale w krajach dziedzicznych monarchii habsburskiej był tylko „współregentem”. Rządził tam razem z matką, która aż do śmierci w 1780 r. miała ostatnie słowo w wielu sprawach państwowych. 
ostro skrytykowana za tryb życia niegodny królowej. Wreszcie ministrowie spodziewali się z jego strony prób ingerencji w wewnętrzne sprawy Francji, co wydawało się tym bardziej realne, że ich monarcha był jeszcze bardzo młody, niedoświadczony i podatny na wpływy. Józef II rozumiał te obawy, toteż od początku zamierzał eksponować ściśle prywatny charakter podróży i unikać podejmowania z własnej inicjatywy tematów, które przez jego rozmówców mogłyby zostać uznane za niewygodne. Taktyka ta okazała się skuteczna, przynajmniej w odniesieniu do rozmów o polityce: wstrzemięźliwość cesarza w tym zakresie została szybko zauważona i doceniona ${ }^{12}$.

Aby jeszcze mocniej podkreślić, że przyjeżdża zupełnie prywatnie, postanowił odbyć całą podróż z zachowaniem ścisłego incognito. Formułę tę często stosowali europejscy władcy lub członkowie rodów panujących, udając się do innych państw. Pozwalała bowiem zawiesić na czas wojażu najbardziej wymagające przepisy etykiety dworskiej, uniknąc męczących, uroczystych wjazdów do miast, powitań czy przemówień. Osoba podróżująca incognito wybierała sobie fikcyjny tytuł arystokratyczny oraz zmyślone nazwisko, które zresztą zwyczajowo nawiązywało do prawdziwej tożsamości podróżnika, gdyż było zapożyczone od domeny, nad którą rzeczywiście sprawował on władzę. Przed wyjazdem te fikcyjne dane personalne podawano do publicznej wiadomości, a wszelkie szczegóły dotyczące sposobu traktowania wojażera ustalano z władzami krajów, przez które miał on przejeżdżać. Nie chodziło przy tym o ukrywanie prawdziwej tożsamości, a jedynie o nadanie wizycie nieoficjalnego charakteru. Osoba taka miała być przyjmowana na obcym dworze odpowiednio do statusu społecznego, jaki reprezentowała podczas podróży: wybór tytułu arystokratycznego oznaczał, że gość będzie podejmowany jak arystokrata, będzie nosił typowe dla arystokracji stroje i nie będzie rościł sobie pretensji do pierwszeństwa w towarzystwie władcy i członków jego rodziny. Na każdym etapie pobytu miał jednak prawo zrezygnować z incognito - jeśliby tak uczynił, zostałby potraktowany oficjalnie i oddawano by mu wszelkie należne honory. Bez względu na to, czy swój status zachowywał, czy też go porzucał, pozostawał pod specjalną opieką władz państwa, na którego terytorium przebywal ${ }^{13}$.

Cesarz Józef II, który wielokrotnie podróżował incognito, za każdym razem przybierał na tę okoliczność nazwisko hrabiego Falkensteina. Stanowiło to dowód przywiązania do lotaryńskiego dziedzictwa jego ojca. Hrabstwo Falkenstein, położone na lewym brzegu Renu, od 1667 roku należało do Lotaryngii. Było ono jedyną częścią księstwa, którą po wojnie o tron polski (1733-1735) pozostawiono w ręku dotychczasowego władcy - Franciszka Stefana - i jego następców ${ }^{14}$. Występując jako „hrabia Falkenstein" (Graf von Falkenstein), cesarz świadomie demaskował się przed opinią publiczną we Francji. Nie było tam tajemnicą, do kogo hrabstwo należy, a poza tym

12 P. de Ségur, op. cit., s. 210-211.

13 V. Barth, Les visites incognito..., s. 323-325; J. Ryba, op. cit., s. 71-72.

14 Lotaryngia przeszła wówczas we władanie Stanisława Leszczyńskiego. Dworowi wiedeńskiemu zależało jednak na tym, aby typowany na przyszłego cesarza Franciszek Stefan Lotaryński zachował jakieś władztwo na terenie Rzeszy, co zwiększałoby jego szanse na uzyskanie tego tytułu. Zob. też A. du Coudray, Anecdotes intéressantes et historiques de l'illustre voyageur pendant son séjour à Paris, dédiées à la Reine, éd. 2, corrigée et augmentéé, Paris 1777, s. 6. 
wiedziano już, kto tradycyjnie używa takiego nazwiska podczas podróży po kontynencie. W ten sposób Józef pokazywał, że zależy mu nie tyle na ukrywaniu się, ile na swobodzie i nieskrępowanym dostępie do miejsc, które chciał we Francji zobaczyć ${ }^{15}$.

Wyruszył w drogę znacznie później niż pierwotnie zakładał, bo dopiero 1 kwietnia 1777 roku, a w trakcie czteromiesięcznej podróży towarzyszyła mu stosunkowo niewielka świta. Jej trzon stanowiło w Paryżu 12 osób. Do najważniejszych postaci w tym gronie zaliczali się: dyplomata Philipp von Cobenzl, członek Nadwornej Rady Wojennej Joseph von Colloredo-Mels und Wallsee, sekretarz cesarza Johann Anton Knecht, a także włoski lekarz w służbie Józefa II - Giovanni Alessandro Brambilla ${ }^{16}$. Knechtowi przypadła rola kronikarza wyprawy: władca każdego wieczoru dyktował mu swe uwagi o wszystkim, co go zaintrygowało danego dnia ${ }^{17}$. Trasa orszaku wiodła między innymi przez Monachium, Stuttgart, Rastatt, Strasburg i Nancy. W początkowej fazie podróży cesarzowi udawało się unikać przesadnego zainteresowania swoją osobą, ale już na ziemiach francuskich witały go nieprzebrane thumy gapiów. Kiedy więc 18 kwietnia po południu dotarł do rogatek Paryża, o żadnej anonimowości nie mogło być już mowy. Podobno uciekł się wówczas do małego podstępu: odłączył się od świty i wraz z Cobenzlem wjechał do miasta zupełnie inną drogą niż pozostałe osoby $\mathrm{z}$ orszaku ${ }^{18}$. Jeśli jednak obawiał się owacyjnego powitania, nic takiego nie nastąpiło, ponieważ z powodu intensywnych opadów deszczu przejazd świty „hrabiego Falkensteina” śledziła zaledwie garstka ludzi ${ }^{19}$. Fatalna pogoda będzie się zresztą utrzymywać w kolejnych dniach. Szwedzki dyplomata w Paryżu Gustaf Philip Creutz pisał w tym czasie do Gustawa III: „Po tym, jak mieliśmy lato w miesiącu marcu, teraz jesteśmy w środku zimy. Mróz jest bardzo ostry i wszyscy są chorzy”20.

Pierwsze kroki cesarz skierował do Małego Luksemburga - rezydencji swego ambasadora Florimonda-Claude'a hrabiego Mercy-Argenteau, znajdującej się w południowej części Paryża. Tu też zatrzymał się na czas pobytu w stolicy, korzystając jednocześnie z gościny w pobliskim Hôtel de Tréville, gdzie od pierwszych chwil mieszkała cała jego świta, w tym również osobisty kucharz ${ }^{21}$. Z niektórych przekazów źródłowych wynika, że hotel służył Józefowi tylko jako miejsce spożywania posiłków, a wszystkie noce (o ile nie był akurat w Wersalu) spędzał w pałacu

15 V. Barth, Les visites incognito..., s. 328.

16 Ibidem, s. 329-330; K. Gutkas, op. cit., 168-169; F. Knopper, Admirateurs autrichiens venus à Versailles à l'époque de Marie-Antoinette [w:] ,,Voyages... Voyages... ”Hommages à Alain Ruiz, Textes réunis par F. Knopper et J. Mondot, Pessac 2010, s. 38.

17 A.R. von Arneth, Graf Philipp Cobenzl und seine Memoiren, Wien 1885, s. 123.

18 K. Gutkas, op. cit., s. 168-169; V. Barth, Les visites incognito..., s. 329-330; A.R. von Arneth, op. cit., s. 123.

19 G. Bordonove, Les Rois qui ont fait la France. Louis XVI. Le Roi-Martyr, Paris 1983, s. 99.

20 Gustaf Philip Creutz do Gustawa III, Paryż, 20 kwietnia 1777 [w:] Le Comte de Creutz, La Suède et les Lumières: lettres de France d'un ambassadeur à son roi (1771-1783), correspondance établie, présentée et annotée par M.M. Beyer, Paris 2006, s. 254.

${ }_{21}$ F. Fejtö, op. cit., s. 161. Zob. F.J.A. Schneidawind, Leben Kaiser Josephs des Zweiten, Hamburg 1846, s. 34; K. Gutkas, op. cit., s. 168; A. Babeau, Les souverains étrangers en France du Xe au XVIII siècle, ,Revue des questions historiques”, R. 37, 1903, t. 29, s. 141. 
ambasadora $^{22}$. Nie sposób już dzisiaj rozstrzygnąć, jak było naprawdę. Jeśli jednak cesarz preferował Hôtel de Tréville, mogło być to podyktowane stanem zdrowia hrabiego Mercy, który cierpiał na hemoroidy ${ }^{23}$. Dolegliwość była dla niego krępująca i bolesna do tego stopnia, iż nie był w stanie wysyłać regularnych raportów do Wiednia (dopiero w połowie czerwca napisał do cesarzowej obszerny list, w którym drobiazgowo zrelacjonował przebieg wizyty jej syna w Paryżu i Wersalu ${ }^{24}$. W związku $\mathrm{z}$ chorobą ambasadora obowiązki protokolarne na pewien czas przejął cesarski minister pełnomocny w Londynie - Ludovico Belgiojoso, wezwany do Paryża już wcześniej na wyraźne życzenie Józefa ${ }^{25}$. To właśnie on towarzyszył dostojnemu gościowi w trakcie pierwszej wizyty w Wersalu, która nastąpiła 19 kwietnia i miała głównie kurtuazyjny i zapoznawczy charakter ${ }^{26}$.

Maria Antonina, bardzo przejęta wizytą brata, powitała go jednak z wielką radością ${ }^{27}$. Obdarzyła go też pełnym zaufaniem, chociaż nieprzyjemnie zaskoczyło ją incognito, którego Józef rygorystycznie przestrzegał, a także ostentacyjna rezygnacja z małego apartamentu pałacowego, jaki oddała mu do dyspozycji. Wprawdzie przez grzeczność przyjął od siostry klucz, ale z zastrzeżeniem, że zatrzyma się tam jedynie wówczas, gdy będzie potrzebował odpoczynku w ciągu dnia ${ }^{28}$. Większość czasu spędzał w Paryżu, jeśli zaś decydował się pozostać na noc w Wersalu, udawał się do miejscowego hotelu Le Juste, gdzie zresztą naprędce z polecenia królowej urządzono dla niego apartament o standardzie wcale nie gorszym niż w królewskim pałacu ${ }^{29}$.

Decyzja Józefa II o zatrzymaniu się na kilka tygodni w stolicy miała przede wszystkim wymiar propagandowy. W jego wojażu do Francji doszukiwano się przecież podtekstów, panował nawet pogląd, że nie znosi on tego kraju, więc ma zapewne nieczyste intencje ${ }^{30}$. Krótka historia cesarskich wizyt w Paryżu też nie skłaniała

22 Zob. np. Gauthier de Simpré, Voyage en France de monsieur le comte de Falckenstein, t. 1, Londres 1778, s. 354; Anthologische Beschreibung der Reise des Herrn Grafen von Falkenstein nach Frankreich 1777, b.m. 1778, s. 35. Wersję tę przyjmuje za wiarygodną choćby V. Barth, Inkognito. Geschichte eines Zeremoniells, München 2013, s. 158.

${ }^{23}$ Anthologische Beschreibung..., s. 35. Zob. też J.H. Schnitzler, op. cit., s. 433.

24 Mercy-Argenteau do Marii Teresy, Paryż, 15 czerwca 1777 [w:] Marie-Antoinette, Correspondance secrète entre Marie-Thérèse et le $C^{t e}$ de Mercy-Argenteau, avec les lettres de Marie-Thérèse et de MarieAntoinette, t. 3, éd. 2, publiée avec une introduction et des notes par A. d'Arneth et A. Geffroy, Paris 1874 , s. $49-84$.

25 Już jesienią 1776 r. cesarz pisał do swego brata Leopolda, że bardzo chciałby poznać osobiście tego dyplomatę, bo dotychczas nie miał ku temu okazji. Zob. Józef II do Leopolda Habsburga, b.m., 29 października 1776 [w:] Maria Theresia und Joseph II..., s. 122-123.

26 A. du Coudray, op. cit., s. 15.

27 Ch. de Larivière, op. cit., s. 608. Zob. też Madame Campan, Mémoires sur la vie privée de Marie-Antoinette, reine de France et de Navarre, éd. 2, t. 1, Paris 1823, s. 174-175.

28 Mercy-Argenteau do Marii Teresy, Paryż, 15 czerwca 1777 [w:] Marie-Antoinette, Correspondance..., s. 52.

29 W.R. Newton, Wersal za fasada przepychu, thum. G. Majcher, Warszawa 2015, s. 20.

${ }^{30}$ Louis-Petit de Bachaumont, Mémoires secrets pour servir á l'histoire de la République des Lettres en France depuis 1762 jusqu'à nos jours ou Journal d'un observateur, t. 10, chez J. Adamson, Londres 1778, s. 91. Podejrzenia te nie były bezpodstawne, w liście do matki Józef zapowiadał bowiem, że chce poznać zarówno silne, jak i słabe punkty monarchii Burbonów, co można było różnie interpretować. 
mieszkańców metropolii do optymizmu. Ani Karol IV Luksemburski, który przybył do tego miasta prawie 400 lat wcześniej (w 1377 roku), ani Karol V Habsburg, który zatrzymał się w nim na krótko w 1540 roku w drodze pod zbuntowaną Gandawę, nie docenili jego zalet, zostali zapamiętani głównie z powodu wydatków wiążących się $\mathrm{z}$ ich wizytami i przepychu, jaki się wokół nich roztaczał ${ }^{31}$. Józef II o tym wiedział, doceniał też znaczenie opinii publicznej we Francji i rozumiał, że aby przysporzyć sobie popularności, musi przede wszystkim zdobyć serca paryżan ${ }^{32}$. Na każdym kroku manifestował więc swoją skromność, otwartość i życzliwy stosunek do zwykłych ludzi. Wyróżniał go prosty, aczkolwiek schludny ubiór. Zazwyczaj miał na sobie surdut i kamizelkę, tradycyjne krótkie spodnie, czarne pończochy i miękkie buty z cholewkami. Nie nosił żadnych ozdób, nie licząc zwykłej czarnej kokardy przy kapeluszu. Na co dzień miał do dyspozycji służących, ale jeśli już korzystał z ich pomocy, wymagał dużego poświęcenia - musieli śledzić jego aktywność z pewnego dystansu, poruszać się często na piechotę i wykazywać cierpliwością, gdy zapragnął się spotkać z kupcami czy artystami, złożyć wizytę w popularnej kawiarni albo pokazać $\mathrm{w}$ jednym $\mathrm{z}$ publicznych ogrodó $\mathrm{w}^{33}$. Tym niewymuszonym, naturalnym sposobem bycia istotnie zaskarbił sobie tutaj ogólną sympatię. „Całą dworu i miasta uwagę obrócił teraz na siebie Cesarz Jmć, którego łagodna przystępność tak powszechnie miłą światu czyni jego osobę" - czytamy w doniesieniach „Gazety Warszawskiej”" Wszyscy chcieli go zobaczyć. W tym celu wchodzono nawet na dachy domostw, a szczególnie oblegany przez mieszkańców Paryża był Hôtel de Tréville ${ }^{35}$. Naoczny świadek, niemiecki pisarz Heinrich Sander, zanotował, że 20 maja 1777 roku zgromadziło się tam ponad tysiąc osób w nadziei ujrzenia cesarza $z$ bliska ${ }^{36}$. Sam Józef twierdził w liście do brata, że ta popularność mu nie przeszkadzała (,trochę ludzi pod moimi drzwiami, kiedy wychodzę, to wszystko") ${ }^{37}$. Odmiennego zdania był Mercy-Argenteau, który informował Marię Teresę, że Józefa II irytowały te publiczne demonstracje sympatii, a także entuzjastyczne owacje na jego cześć, gdy pojawiał się $\mathrm{w}$ teatrze ${ }^{38}$. Być może właśnie dlatego, kiedy tylko mógł, próbował wyprowadzać

Zob. Józef II do Marii Teresy Habsburg, bm., 24 listopada 1776 [w:] Maria Theresia und Joseph II..., s. $124-125$.

31 A. du Coudray, op. cit., s. 40-41, 60-61. Zob. F. Seibt, Karol IV. Cesarz w Europie 1346-1378, tłum. C. Tarnogórski, Warszawa 1996, s. 342-343; A. Babeau, op. cit., s. 131-132.

32 F. Fejtö, op. cit., s. 163.

33 Anthologische Beschreibung..., s. 75; Ch.-J. de Mayer, Monsieur le comte de Falkenstein, ou Voyages de l'empereur Joseph II en Italie, en Bohême et en France, contenant un précis des établissements utiles faits depuis le règne de Marie-Thérèse, éd. 2 considérablement augmentée, Rome-Paris 1778, s. 159.

34 Z Paryża, dnia 25 kwietnia, „Gazeta Warszawska”, 24 maja 1777, nr 42.

35 Gauthier de Simpré, op. cit., s. 354-355.

36 H. Sander, Beschreibung seiner Reisen durch Frankreich, die Niederlande, Holland, Deutschland und Italien, in Beziehung auf Menschenkenntnis, Industrie, Litteratur und Naturkunde insonderheit, t. 1, Leipzig 1783, s. 40.

37 Józef II do Leopolda Habsburga, Paryż, 29 kwietnia 1777 r. [w:] Maria Theresia und Joseph II..., s. 130

38 Mercy-Argenteau do Marii Teresy, Paryż, 15 czerwca 1777 [w:] Marie-Antoinette, Correspondance..., s. 77. 
paryżan w pole, usypiać ich czujność i pojawiać się znienacka tam, gdzie nikt się go nie spodziewał. Według jednej z popularnych anegdot wpadł nierozpoznany do sławnej Café de la Régence, by rozegrać partię szachów, ale prawie nikogo nie zastał w środku, gdyż jak mu wyjaśniono, wszyscy bywalcy kawiarni pobiegli zobaczyć cesarza, którego oczekiwano przed Palais-Royal ${ }^{39}$. Inna wersja tej historii jest nieco bardziej optymistyczna: monarcha znalazł partnera do gry, ale rywal już na początku rozgrywki zasugerował, by ją przełożyć na wieczór albo na następny dzień, ponieważ bardzo mu się śpieszy się pod Palais-Royal, gdzie lada chwila ma dotrzeć cesarz ${ }^{40}$.

Józef II usiłował dyskretnie powstrzymywać falę entuzjazmu dla swojej osoby. Już na początku pobytu zastrzegł, że nie będzie przyjmował u siebie żadnych gości i nie życzy sobie, aby zwracano się do niego z prośbami albo też ofiarowywano mu jakieś dzieła literackie bądź artystyczne. Nie miało to jednak większego znaczenia. Sam Mercy-Argenteau wspominał, że codziennie dostawał setki listów adresowanych do cesarza, na które, gdyby nawet chciał, nie byłby w stanie odpowiedziećc ${ }^{41}$. Władca został też dosłownie zasypany okolicznościowymi mowami, wierszami, dedykacjami, prośbami i pochlebstwami ${ }^{42}$. Utwory ku czci cesarza wydawano przeważnie anonimowo, ale współcześni i tak potrafili zidentyfikować wielu autorów. Na tej liście znaleźli się między innymi: była metresa Ludwika XV, Anne Thoynard de Jouy hrabina d'Esparbès de Lussan ${ }^{43}$, uznani już francuscy literaci, jak Marie-Antoine-François Chivot, Bernard-Joseph Saurin, Pierre-Charles Cosson, Claude-Joseph Dorat czy Antoine de Laurès, a także młoda i obiecująca poetka Charlotte-Catherine Cosson de La Cressonnière ${ }^{44}$. Akcentowali oni głównie motyw cesarskiego incognito, o którym pisano, że jest daremne, gdyż im bardziej gość ukrywa przed światem swój tytuł cesarza, tym więcej każe podziwiać w sobie człowieka ${ }^{45}$. Wychwalali również jego przystępność i skromnośćc ${ }^{46}$. Poza dziełami literackimi powstawały też wyobrażenia ikonograficzne gościa - osobiście zresztą nabył $\mathrm{w}$ jednym z paryskich butików czterdzieści rycin z własnym wizerunkiem, bardzo zaskoczony faktem, że są one wyjątkowo tanie, zaledwie po 12 solidów za sztukę. „To wcale nie drogo za cesarza" - skomentował z właściwym sobie sarkazmem, i był to jeden $\mathrm{z}$ tych bon motów, które przysparzały mu tutaj nadzwyczajnej popularności i uznania ${ }^{47}$.

O ile paryżanie z miejsca polubili tego ekscentrycznego przybysza, o tyle na dworze wersalskim zdania na jego temat były podzielone. Dobrze oceniał go doświadczony francuski dowódca, a zarazem bystry obserwator życia wersalskiego tej

39 A. du Coudray, op. cit., s. 21-22.

40 Ibidem, s. 21-23.

41 Mercy-Argenteau do Marii Teresy, Paryż, 15 czerwca 1777 [w:] Marie-Antoinette..., s. 55-56.

42 Mémoires de la baronne d'Oberkirch sur la cour de Louis XVI et la société française avant 1789, Édition présentée et annotée par S. Burkard, Paris 2004, s. 127.

43 Louis-Petit de Bachaumont, op. cit., t. 10, s. 154.

44 G. de Simpré, op, cit., t. 1, s. 356 i n.

45 Louis-Petit de Bachaumont, op. cit., t. 10, s. 159.

46 A. de Laurès, Épître à l'Empereur, ,Mercure de France”, Juin 1777, s. 177-178.

47 A. du Coudray, op. cit., s. 122. Wszystkie tego rodzaju wypowiedzi cesarza paryska publiczność skrzętnie odnotowywała, uważając je za pełne dobrego smaku. Zob. Louis-Petit de Bachaumont, op. cit., t. 10, s. 126. 
doby - Emmanuel diuk de Croÿ. W swym dzienniku przyznawał, że cesarz prezentował się korzystnie (lepiej niż na przedstawiających go portretach), zachowywał się swobodnie i grzecznie, biegle władał francuskim (aczkolwiek zdarzało mu się używać oryginalnych konstrukcji słownych), a tym, co robiło największe wrażenie, była wstrzemię́liwość, z jaką odnosił się do dworskich rozrywek, szczególnie gier hazardowych i konwersacji z damami ${ }^{48}$. Zgoła odmiennie scharakteryzowała cesarza Jeanne-Louise-Henriette Campan, przyjaciółka i dama dworu Marii Antoniny. Utrzymywała, że był on postacią niedyskretną i niewdzięczną. Bez skrępowania ujawniał na przykład pikantne szczegóły z życia dworskiego Neapolu, Parmy, a nawet Wiednia. $Z$ rozbawieniem komentował sceny zazdrości rozgrywające się pomiędzy królem i królową Neapolu, kończące się tym, że królowa nie chciała wpuszczać męża do wspólnego łoża. Rzecz to o tyle ciekawa, że bohaterką tych skandalizujących opowieści była rodzona siostra Józefa II - Maria Karolina ${ }^{49}$.

Chociaż był tylko gościem na dworze, pozwalał sobie na daleko posuniętą krytykę panującej tam etykiety i obyczajów, nie wahał się też publicznie strofować króla i królowej. Ludwikowi XVI w obecności innych osób wytknął, zresztą nie bez racji, że nie zna swojego państwa ani nawet stolicy, skoro nie był ani razu w gmachu Szkoły Wojskowej czy w Hotelu Inwalidów. Marii Antoninie publicznie zarzucił z kolei brak odpowiedzialności i wyśmiewał jej przesadne zamiłowanie do kosmetyków oraz wymyślnych strojów i fryzur ${ }^{50}$. Nie przypadł mu też do gustu ceremoniał dworu wersalskiego. Wychodząc z uroczystego coucher Ludwika XVI, miał zgryźliwie powiedzieć: „Gdyby było mi potrzeba tylu ceremonii do położenia się do łóżka, to sądzę, że nigdy bym się nie położył" ${ }^{51}$. W liście do brata z 11 maja zamieścił uwagi zdecydowanie przekraczające granice dobrego smaku. Przedstawił tam króla jako osobę chwiejną i źle wychowaną, zaś o jego bratowej, hrabinie Artois Marii Teresie Sabaudzkiej, napisał wręcz, że jest „absolutnie imbecylowata” - doprawdy trudno się dziwić pani Campan, że żywiła wobec gościa intuicyjną niechęćs ${ }^{52}$.

Najpilniejszym zadaniem, z jakim przyszło mu się zmierzyć w czasie wizyty we Francji, było zażegnanie kryzysu małżeńskiego trapiącego parę monarszą. Nawet dziś, po wielu latach, trudno dociec, w czym tkwiło źródło intymnych problemów Ludwika XVI i Marii Antoniny, ponieważ nie dysponujemy odpowiednią dokumentacją medyczną. Józef II pisał z dużą dozą ironii do Leopolda, że małżonkowie byli po prostu niedojrzali psychicznie, nieuświadomieni i nieporadni w sferze seksu, a ponadto apatyczni i leniwi ${ }^{53}$. Choć stwierdzenie to niczego właściwie nie przesądza, część historyków na nim właśnie poprzestaje, podkreślając, że unikanie współżycia

48 Journal inédit du duc de Crö̈ 1718-1784, t. 4, publié par le Vte de Grouchy et P. Cottin, Paris 1907, s. 10-12.

49 Madame Campan, op. cit., t. 1, s. 182-183.

50 Ibidem, s. 175-180.

51 Gustaf Philip Creutz do Gustawa III, Paryż, 24 kwietnia 1777 [w:] Le Comte de Creutz..., s. 255.

52 Józef II do Leopolda Habsburga, Paryż, 11 maja 1777 [w:] Maria Theresia und Joseph II..., s. $133-134$.

53 F. Fejtö, op. cit., s. 167; J.-Ch. Petitfils, op. cit., s. 313. 
wynikało z niezręczności oraz niskiej kultury seksualnej pary królewskiej ${ }^{54}$. Niektórzy badacze przypuszczają jednak, że przyczyną kłopotów mogła być stulejka, rzekomo utrudniająca Ludwikowi XVI podjęcie współżycia. Biorąc pod uwagę fakt, iż to męskie schorzenie występuje w mniej lub bardziej rozwiniętej formie, jest całkiem możliwe, że przez długi czas lekarze nie potrafili go zdiagnozować. Usunięcie stulejki wymagałoby drobnej ingerencji chirurgicznej, na którą król miałby się zdecydować dopiero pod wpływem Józefa II. Nawet krótka operacja w epoce, w której nie znano jeszcze znieczulenia, była bolesna i groziła powikłaniami, ale zakładając, że cesarz dodał swemu szwagrowi otuchy, taki zabieg mógł rzeczywiście zostać wykonany, tym bardziej że jeden z lekarzy królewskich - Joseph-Marie-François de Lassonne - uchodził za najlepszego francuskiego specjalistę w leczeniu tej przypadłości ${ }^{55}$. Medyk ten zresztą 27 maja spotkał się z cesarzem w Wersalu - nie wiadomo, o czym dyskutowali, ale intrygująco brzmi świadectwo hrabiego Mercy, który napisał, że Józef II zaraz po zakończeniu spotkania udał się do siostry i przeprowadził z nią rozmowę, która momentami wprawiała królową w zakłopotanie. Możliwe, że de Lassonne przekazał cesarzowi jakieś informacje bądź wskazówki dotyczące stanu zdrowia pary królewskiej, brak jednak dowodów na to, by miał przeprowadzić operację króla ${ }^{56}$. Istnieje jeszcze jedna hipoteza dotycząca natury problemu, z jakim borykali się król i jego żona. Przenosi ona przynajmniej część odpowiedzialności za niedopełnienie tego związku z Ludwika XVI na Marię Antoninę. Jak pisze Jean-Christian Petitfils, królowa przez długi czas nie była psychicznie gotowa do współżycia, a zwłaszcza do macierzyństwa. Myśli o dziecku odkładała na później, a próby podjęcia kontaktów seksualnych przez męża wywoływały u niej reakcje lękowe i skurcze, wzmagające dyskomfort monarchy, a nawet powodujące u niego fizyczny ból. Według tej koncepcji przyczyną nieudanego pożycia nie byłaby stulejka Ludwika XVI, lecz pochwica Marii Antoniny, czyli dysfunkcja seksualna nasilająca się zapewne w wyniku ponagleń i krytycznych uwag napływających regularnie od jej matki z Wiednia ${ }^{57}$.

Bezsporny jest fakt, że wizyta Józefa II doprowadziła do poprawy relacji między królem i królową. Proces ten był prawdopodobnie dość powolny, skoro pełna konsumpcja małżeństwa nastąpiła dopiero 18 sierpnia 1777 roku, najważniejsze jednak, że w tej kwestii cesarz osiągnął pełny sukces ${ }^{58}$. Nie udało mu się natomiast skłonić Marii Antoniny do porzucenia beztroskiego zachowania i rozrywek nielicujących

${ }^{54}$ J. Baszkiewicz, op. cit., s. 85; A. Fraser, op. cit., s. 204-205. Zob. B. Vincent, Louis XVI, Paris 2006, s. 78 i n.

55 G. Androutsos, Le phimosis de Louis XVI (1754-1793) aurait-il été à l'origine de ses difficultés sexuelles et de sa fécondité retardée?, „Progrès en Urologie” 2002, vol. 12, n 1, s. 136. Zob. F. Fejtö, op. cit., s. 167; S. Zweig, Maria Antonina, thum. Z. Petersowa, Katowice 1984, s. 23.

56 Mercy-Argenteau do Marii Teresy, Paryż, 15 czerwca 1777 [w:] Marie-Antoinette..., s. 73. Zdaniem É. Lever nie sposób ani jednoznacznie potwierdzić, ani też stanowczo zaprzeczyć wersji o interwencji chirurgicznej. Zob. eadem, Louis XVI, s. 293.

57 J.-Ch. Petitfils, op. cit., s. 310-311. Zob. B. Craveri, Kochanki i królowe. Władza kobiet, thum. P. Salwa, Warszawa 2008, s. 304-305. Na temat tego zaburzenia zob. Seksuologia. Zarys encyklopedyczny, red. K. Imieliński, Warszawa 1985, s. 270-271.

58 É. Lever, Louis XVI, s. 293. 
z powagą królowej Francji. Nie bardzo zresztą wiedział, jak przemówić siostrze do rozsądku, przeplatał więc surowość z łagodnością. Niekiedy ganił ją publicznie za brak uległości, za przesadną śmiałość w wypowiedziach i za lekceważenie męża. Pod wpływem ambasadora Mercy'ego porzucił jednak ten ostry ton i próbował apelować do niej w sposób bardziej konfidencjonalny. Nalegał, by usunęła ze swego otoczenia nieodpowiednie osoby i pozyskała sobie ludzi oddanych i lojalnych, by spróbowała poznać swoich poddanych i zdobyć ich sympatię, wreszcie, by wyzbyła się skłonności do hazardu i trwonienia pieniędzy na klejnoty. Rezultaty tego rodzaju perswazji były jednak mizerne ${ }^{59}$.

Całkowitą porażkę poniósł Józef II w staraniach o umocnienie sojuszu austriacko-francuskiego, a zwłaszcza o pozyskanie pomocy w sporze o sukcesję bawarską. Po spodziewanej w niedługim czasie śmierci księcia Maksymiliana III Józefa zamierzał zbrojnie zająć Bawarię i nie dopuścić, by władzę w Monachium przejął kuzyn tego monarchy i jego prawowity następca - elektor palatyn reński Karol Teodor. Co najwyżej gotów był przekazać temu ostatniemu Niderlandy Austriackie jako odszkodowanie. $Z$ punktu widzenia interesów cesarza Bawaria byłaby nabytkiem znacznie cenniejszym niż odległa od Austrii, obca jej kulturowo i trudna do obrony prowincja „belgijska”. Zajęcie Bawarii zrekompensowałoby Habsburgom utratę Śląska, oznaczałoby też umocnienie ich pozycji w Europie Środkowo-Wschodniej, tym bardziej że był to kraj niemieckojęzyczny, katolicki, dobrze rozwinięty gospodarczo i dysponujący niezłą armią. Co ciekawe, sam Karol Teodor wcale nie spieszył się z objęciem rządów w Bawarii i łatwo dał się przekonać do negocjacji z Habsburgami w kwestii wymiany terytoriów ${ }^{60}$. Takiego rozwiązania nie zamierzał jednak zaakceptować Fryderyk Wielki, gdyż naruszałoby ono równowagę sił w Rzeszy. W obliczu nadchodzącej konfrontacji z Prusami cesarz potrzebował sojusznika, dlatego w poufnych rozmowach z ministrem spraw zagranicznych Ludwika XVI Charles'em de Vergennesem wysunął propozycję przyłączenia do Francji co najmniej części Niderlandów Austriackich w zamian za wsparcie. Gabinetu wersalskiego nie interesowały jednak takie nabytki terytorialne, nie mógł się też angażować w awanturę wojenną na terenie Rzeszy w chwili, gdy coraz poważniej rozważał przyłączenie się do wojny z Wielką Brytanią po stronie kolonistów amerykańskich. Vergennes nigdy zresztą nie należał do entuzjastów sojuszu z Wiedniem, bez wahania odrzucił więc sugestie Józefa II. Nie przeszkodziło to jednak cesarzowi w dokonaniu inwazji na Bawarię w 1778 roku i rozpoczęciu zmagań militarnych z królem pruskim. Jeśli jednak liczył, że drogą faktów dokonanych wciągnie do walk francuskiego sojusznika, to srodze się rozczarował. Jego apele o pomoc zbrojną nie odniosły skutku, gdyż w Wersalu konsekwentnie uznawano, że sojusz między Francją i Austrią ma charakter defensywny i użycie wojsk francuskich w konflikcie, w którym cesarz jest agresorem, nie wchodzi

59 Mercy-Argenteau do Marii Teresy, Paryż, 15 czerwca 1777 [w:] Marie-Antoinette..., s. 79-80. Zob. też J. Bérenger, Joseph II d'Autriche serviteur de l'État, Paris 2007, s. 228-229.

60 Początkowo mówiło się o cesji jedynie części Bawarii, z czasem jednak Józef II zaczął myśleć o zagarnięciu całości jej terytorium. Zob. F. Fejtö, op. cit., s. 170. 
w grę ${ }^{61}$. Takie stanowisko na pewno bolało Józefa II, dowodziło przede wszystkim, że polityczne rezultaty jego podróży do Francji były więcej niż skromne ${ }^{62}$.

Każdą wolną chwilę „hrabia Falkenstein” poświęcał na zwiedzanie Paryża i jego okolic. Poznawał pałace królewskie i książęce, odbywał przechadzki po bulwarach, promenadach i ogrodach. Wizytował szkoły, szpitale i przytułki, a także niedawno wzniesione gmachy publiczne stanowiące wizytówkę stolicy (m.in. Halę Zbożową, Mennicę Królewską oraz Koloseum, które w założeniu miało spełniać rolę paryskiego centrum rozrywki). Zwiedzał manufaktury wytwarzające tkaniny, porcelanę i dywany, za każdym razem inicjując rozmowy z robotnikami ${ }^{63}$. Był częstym gościem wielkich scen Paryża (Komedii Francuskiej, Komedii Włoskiej i Opery), nie gardził jednak także wizytami w teatrach bulwarowych oraz w salach koncertowych. Pojawiał się w pracowniach malarzy i rzeźbiarzy oraz w gabinetach naukowców. Podziwiał wnętrza największych stołecznych kościołów (Notre Dame, Saint-Sulpice i Saint-Roch), śledził postępy prac przy budowie nowej świątyni pod wezwaniem Świętej Genowefy (dzisiejszego Panteonu), wreszcie udał się do nekropolii królewskiej w Saint-Denis. W tamtejszym klasztorze Karmelitanek złożył wizytę siostrze Teresie od św. Augustyna: pod tym imieniem wypełniała swoje powołanie zakonne najmłodsza córka Ludwika XV i Marii Leszczyńskiej - Luiza ${ }^{64}$.

Jego wrażenia „turystyczne” wydają się ambiwalentne. 11 maja, po trzech tygodniach pobytu w stolicy, zwierzył się swemu bratu, że choć znajdują się tam budowle wspaniałe, wyrafinowane i zwracające uwagę, to niewiele jest konstrukcji przynoszących realny pożytek mieszkańcom miasta ${ }^{65}$. Nieco rozczarował go poziom widowisk teatralnych (wyjąwszy może spektakle w Komedii Francuskiej) ${ }^{66}$. Nie spodobały mu się niektóre rozrywki dworu, szczególnie wyścigi konne, które miał okazję obserwować, korzystając z zaproszenia siostry ${ }^{67}$. Codziennie spotykał się jednak z ciekawymi ludźmi i konsekwentnie gromadził informacje o francuskiej gospodarce, administracji oraz infrastrukturze. Nieprzypadkowo do grona jego najważniejszych rozmówców zaliczali się: Anne-Robert Turgot (były kontroler generalny finansów), Jacques Necker (aktualny szef tego resortu), Jean-Joseph de Laborde (bankier dworu), Louis Berthier de Sauvigny (intendent Paryża), a także Philibert Trudaine de Montigny

${ }_{61}$ J. Bérenger, J. Meyer, La France dans le monde au XVIII siècle, Paris 1993, s. 345-347. Zob. J. Bérenger, op. cit., s. 227-228. Zob. też G. Zeller, Les temps modernes. II: De Louis XIV à 1789 [w:] Histoire des relations internationales, t. 3, sous la dir. de P. Renouvin, Paris 1955, s. 291.

62 Już po zakończeniu konfliktu o sukcesję bawarską w 1779 r. cesarz miał bardzo chłodno potraktować francuskiego dyplomatę Louisa-Auguste'a de Breuteuila, nie kryjąc rozczarowania powściągliwą postawą dworu wersalskiego, mimo że to przecież dzięki mediacji francuskiej (i rosyjskiej) udało się podpisać pokój w Cieszynie. Zob. F. Fejtö, op. cit., s. 180-181.

${ }^{63}$ A. du Coudray, op. cit., s. 67-69.

${ }_{64}$ Wykaz odwiedzonych miejsc zamieszcza Abbé Duval-Pyrau, Journal et anecdotes intéressantes du voyage de monsieur le comte de Falckenstein, Francfort-Leipsic 1777, s. 1-13.

${ }_{65}$ Józef II do Leopolda Habsburga, Paryż, 11 maja 1777 [w:] Maria Theresia und Joseph II..., s. 132 .

66 Zob. Journal inédit du duc de Crö̈..., s. 41.

67 Gustaf Philip Creutz do Gustawa III, Paryż, 27 kwietnia 1777 [w:] Le Comte de Creutz..., s. $257-258$. 
(dyrektor Biura Mostów i Dróg) ${ }^{68}$. Rozmowy z Turgotem zaowocują w dobie reform józefińskich, gdy cesarz weźmie pod uwagę niektóre koncepcje ekonomiczne tego wybitnego przedstawiciela szkoły fizjokratów ${ }^{69}$.

Skorzysta również z francuskich doświadczeń w zakresie filantropii. Od 1760 roku funkcjonował w Paryżu przy ulicy des Moulins zakład edukacyjny dla osób głuchych, niemych i niedosłyszących, założony przez księdza Charles'a-Michela de l'Épée. Duchowny ten uczył swoich podopiecznych porozumiewania się za pomocą gestów, nazywanych przez siebie „znakami metodycznymi" ${ }^{\text {" }}$. Cesarz, który złożył mu wizytę, był tym bardzo zaintrygowany i zaczął myśleć o utworzeniu analogicznej instytucji w Wiedniu, co mu się zresztą uda już w $1779 \mathrm{roku}^{71}$. Inspiracją będą też dla niego niektóre paryskie zakłady opiekuńczo-lecznicze, nieco na wyrost nazywane „szpitalami” (bo nie wszystkie zajmowały się wyłącznie leczeniem, często ich zadaniem było izolowanie od społeczeństwa osób kalekich, niedołężnych, skrajnie ubogich lub zdeprawowanych ${ }^{72}$. Józef II dostrzegał w tych placówkach duży potencjał i doświadczenia paryskie wywrą pewien wpływ na jego późniejszą politykę społeczną. Między innymi wiedeński Szpital Powszechny zostanie w latach 1783-1784 przebudowany według planów Hôtel-Dieu - największej w stolicy Francji instytucji zajmującej się opieką nad chorymi ${ }^{73}$.

Można przypuszczać, że z dużą przyjemnością wizytował miejsca i instytucje związane z wojskiem. Uczestniczył między innymi w uroczystym przeglądzie Gwardii Francuskiej i Gwardii Szwajcarskiej na równinie Sablons w obecności całego dworu. Odwiedził koszary i szpital wojskowy dla gwardzistów, był również w okazałym budynku Szkoły Wojskowej i aż dwukrotnie w Hotelu Inwalidów, który uważał podobno za najpiękniejszy gmach publiczny w całym Paryżu ${ }^{74}$. W tym wypadku nie musiał jednak kopiować wzorców francuskich, bo uczynił to już Karol VI w latach 20. XVIII wieku. Przytułki dla inwalidów wojennych powstały wtedy nie tylko w Wiedniu, ale również w Peszcie i Pradze ${ }^{75}$.

W sumie należy podkreślić, że mimo zawodu, jakiego na pewno doznał w kwestiach politycznych, Józef II uważał swój sześciotygodniowy pobyt w Paryżu i Wersalu za udany. Zrealizował w tym czasie większość celów, jakie przed sobą postawił.

68 Mercy-Argenteau do Marii Teresy, Paryż, 15 czerwca 1777 [w:] Marie-Antoinette..., s. 58-59, 73.

69 H. Reinalter, op. cit., s. 55-56; F. Fejtö, op. cit., s. 279 i n.

70 J.-R. Presneau, L'éducation des sourds et muets, des aveugles et des contrefaits au Siècle des Lumières 1750-1789, Paris 2010, s. 140-149; R. Niedziela, Paryż przed Rewolucja (1774-1789). Obraz miasta w oczach cudzoziemców, Kraków 2015, s. 171.

${ }_{71}$ Louis-Petit de Bachaumont, op. cit., t. 10, s. 148-149; F. Weissensteiner, Habsburgowie, thum. B. i D. Lulińscy, Warszawa 2011, s. 246.

72 R. Niedziela, op. cit., s. 166 i n.

73 H. Reinalter, op. cit., s. 56; D. Beales, Joseph II, vol. I: In the Shadow of Maria Theresa 1741-1780, Cambridge University Press 1987, s. 379.

74 Szerzej Gauthier de Simpré, op. cit., s. 264-271. Zob. Ch. de Larivière, op. cit., s. 615.

75 A. Wyrobisz, Żotnierze, weterani, inwalidzi wojenni - nowy problem spoleczny $w$ miastach europejskich XVI-XVIII w. [w:] Wojsko. Społeczeństwo. Historia, Prace ofiarowane Profesorowi Mieczysławowi Wrzoskowi w sześćdziesiąta piąta rocznice Jego urodzin, red. W. Fedorowicz, J. Snopko, Białystok 1995, s. 93. 
Poznał wybitnych reprezentantów francuskiej kultury i nauki, wśród nich także de Buffona. Monarcha już na wstępie wyjaśnił mu, że przybywa po książkę, której przed dwoma laty zapomniał zabrać jego brat Maksymilian (uczony miał mu na to odpowiedzieć, że ma dla niego inny tytuł, bardziej odpowiadający upodobaniom cesarza $)^{76}$. Z czasem jednak zainteresowanie osobą gościa wyraźnie spadło. „Być może za bardzo przyzwyczajono się do jego widoku; uczucia, jakie wzbudzał, zużyły się; prostota się podoba, ale na dłuższą metę wydaje się mało ciekawa" - stwierdziła filozoficznie jedna z jego rozmówczyń, markiza du Deffand ${ }^{77}$. Opuścił Paryż w tajemnicy przed mieszkańcami, nocą z 30 na 31 maja 1777 roku $^{78}$. Podsumowując w korespondencji z bratem swój pobyt w metropolii, przyznał, że bardziej niż pożegnania z tym miastem, żałował rozstania $\mathrm{z}$ Wersalem, gdzie pozostała - pogrążona w smutku i we łzach - jego siostra. Wystawił jej na odjezdnym zaskakująco wysoką ocenę, podkreślając, że jest miłą, szczerą i cnotliwą dziewczyną, choć niezbyt rozważną (co jednak złożył na karb jej młodego wieku) ${ }^{79}$. Na tym etapie francuskiej podróży to właśnie dla niej uczynił najwięcej dobrego: dodał jej pewności siebie, nadał nowy wymiar jej życiu małżeńskiemu, wytknął dotychczas popełniane błędy i zaapelował, by je naprawiła. W dłuższej perspektywie miało się okazać, że oddał jej również niedźwiedzią przysługę. Na swoim przykładzie ujawnił bowiem przed Francuzami tak pożądane u monarchy cechy, jak skromność, oszczędność i odpowiedzialność. Pokazał im pewien ideał, do którego Maria Antonina nigdy się nawet nie zbliży. Wręcz przeciwnie, jej nieustająca rozrzutność, frywolność i beztroska spowodują dalszy spadek popularności ${ }^{80}$. Tego niekorzystnego trendu nie zdoła już odwrócić ponowna wizyta Józefa II w Paryżu i Wersalu, złożona latem 1781 roku. Jakkolwiek również odbyta incognito, to jednak była o wiele krótsza (trwała zaledwie tydzień), dużo skromniejsza (monarsze towarzyszyło tym razem jedynie sześć osób) i nie miała podobnego oddźwięku w ówczesnych środkach społecznego przekazu ${ }^{81}$.

\section{BIBLIOGRAFIA}

\section{Źródła}

Anthologische Beschreibung der Reise des Herrn Grafen von Falkenstein nach Frankreich 1777, b.m. 1778.

Le Comte de Creutz, La Suède et les Lumières: lettres de France d'un ambassadeur à son roi (1771-1783), correspondance établie, présentée et annotée par M.M. Beyer, Paris 2006.

76 Louis-Petit de Bachaumont, t. 10, s. 151.

77 Lettres de la marquise du Deffand à Horace Walpole, écrites dans les années 1766 à 1780, t. 2, éd. A. Thiers, Paris 1864, s. 267.

78 Ch.-J. de Mayer, op. cit., s. 183.

79 Józef II do Leopolda Habsburga, Brest, 9 czerwca 1777 [w:] Maria Theresia und Joseph II..., s. 138 .

${ }^{80}$ P. de Ségur, op. cit., s. 220.

81 F. Knopper, op. cit., s. 39; F. Fejtö, op. cit., s. 223-224. 
Coudray A. du, Anecdotes intéressantes et historiques de l'illustre voyageur pendant son séjour à Paris, dédiées à la Reine, éd. 2, corrigée et augmentéé, Paris 1777.

Duval-Pyrau Abbé, Journal et anecdotes intéressantes du voyage de monsieur le comte de Falckenstein, Francfort-Leipsic 1777.

Gauthier de Simpré, Voyage en France de monsieur le comte de Falckenstein, t. 1, Londres 1778.

„Gazeta Warszawska”, 24 maja 1777, nr 42.

Journal inédit du duc de Crö̈ 1718-1784, t. 4, publié par le V $\mathrm{V}^{\text {te }}$ de Grouchy et P. Cottin, Paris 1907.

Lettres de la marquise du Deffand à Horace Walpole, écrites dans les années 1766 à 1780 , t. 2, éd. A. Thiers, Paris 1864.

Louis-Petit de Bachaumont, Mémoires secrets pour servir á l'histoire de la République des Lettres en France depuis 1762 jusqu'à nos jours ou Journal d'un observateur, t. 10, chez J. Adamson, Londres 1778.

Madame Campan, Mémoires sur la vie privée de Marie-Antoinette, reine de France et de Navarre, t. 1, éd. 2, Paris 1823.

Maria Theresia und Joseph II. Ihre Correspondenz sammt Briefen Joseph's an seinen Bruder Leopold, Band 2, hsg. von A.R. von Arneth, Wien 1867.

Marie-Antoinette, Correspondance secrète entre Marie-Thérèse et le $C^{\text {te }}$ de Mercy-Argenteau, avec les lettres de Marie-Thérèse et de Marie-Antoinette, t. 3, éd. 2, publiée avec une introduction et des notes par A. d'Arneth et A. Geffroy, Paris 1874.

Mayer Ch.-J. de, Monsieur le comte de Falkenstein, ou Voyages de l'empereur Joseph II en Italie, en Bohême et en France, contenant un précis des établissements utiles faits depuis le règne de Marie-Thérèse, éd. 2 considérablement augmentée, Rome-Paris 1778.

Mémoires de la baronne d'Oberkirch sur la cour de Louis XVI et la société française avant 1789, édition présentée et annotée par S. Burkard, Paris 2004.

„Mercure de France”, Juin 1777.

Sander H., Beschreibung seiner Reisen durch Frankreich, die Niederlande, Holland, Deutschland und Italien, in Beziehung auf Menschenkenntnis, Industrie, Litteratur und Naturkunde insonderheit, t. 1, Leipzig 1783.

\section{Opracowania}

Androutsos G., Le phimosis de Louis XVI (1754-1793) aurait-il été à l'origine de ses difficultés sexuelles et de sa fécondité retardée?, „Progrès en Urologie” 2002, vol. 12, n 1 , s. $132-137$.

Arneth A.R. von, Graf Philipp Cobenzl und seine Memoiren, Wien 1885.

Babeau A., Les souverains étrangers en France du $X^{e}$ au XVIII ${ }^{e}$ siècle, „Revue des questions historiques", R. 37, 1903, t. 29, s. 121-146.

Barth V., Inkognito. Geschichte eines Zeremoniells, München 2013.

Barth V., Les visites incognito à la cour des Bourbons au XVIII ${ }^{e}$ siècle, trad. de l'allemand par J.-L. Muller [w:] Voyageurs étrangers à la cour de France 1589-1789: regards croisés, sous la direction de C. Zum Kolk, J. Boutier, B. Klesmann et F. Moureau, Rennes-Versailles 2014, s. 323-335.

Baszkiewicz J., Ludwik XVI, Wrocław 1983. 
Beales D., Joseph II, vol. I: In the Shadow of Maria Theresa 1741-1780, Cambridge University Press 1987.

Bély L., La société des princes XVI -XVIII siècle, Paris 1999.

Bérenger J., Joseph II d'Autriche serviteur de l'État, Paris 2007.

Bérenger J., Meyer J., La France dans le monde au XVIII siècle, Paris 1993.

Bordonove G., Les Rois qui ont fait la France. Louis XVI. Le Roi-Martyr, Paris 1983.

Craveri B., Kochanki i królowe. Władza kobiet, tłum. P. Salwa, Warszawa 2008.

Fejtö F., Józef II Habsburg rewolucjonista, tłum. A. Kołodziej, Warszawa 1993.

Fraser A., Maria Antonina. Podróż przez życie, tłum. I. Stąpor, Warszawa 2006.

Gutkas K., Kaiser Joseph II. Eine Biographie, Wien-Darmstadt 1989.

Henwood A., L'empereur Joseph II à la découverte de la marine et de la France de l'Ouest (juin 1777), „Annales de Bretagne et des pays de l'Ouest” 1984, vol. 91, nr 4, s. 351-368.

Histoire des relations internationales, t. 3, sous la dir. de P. Renouvin, Paris 1955.

Knopper F., Admirateurs autrichiens venus à Versailles à l'époque de Marie-Antoinette

[w:] „Voyages... Voyages...” Hommages à Alain Ruiz, Textes réunis par F. Knopper et J. Mondot, Pessac 2010, s. 35-51.

Larivière Ch. de, L'empereur Joseph II à Paris en 1777 et en 1781, „Revue Politique et Parlementaire", R. 8, avril-juin 1901, t. 28, s. 605-631.

Lever É., C'était Marie-Antoinette, Paris 2010.

Lever É., Louis XVI, Nouvelle édition, Paris 2014.

Newton W.R., Wersal za fasada przepychu, thum. G. Majcher, Warszawa 2015.

Niedziela R., Paryż przed Rewolucją (1774-1789). Obraz miasta w oczach cudzoziemców, Kraków 2015.

Petitfils J.-Ch., Louis XVI, t. I: 1754-1786, Paris 2010.

Presneau J.-R., L'éducation des sourds et muets, des aveugles et des contrefaits au Siècle des Lumières 1750-1789, Paris 2010.

Reinalter H., Die Frankreichreise Josephs II. 1777 [w:] „Voyages... Voyages...” Hommages à Alain Ruiz, Textes réunis par F. Knopper et J. Mondot, Pessac 2010, s. 53-60.

Ryba J., Kamuflaże oświeconych: „incognito” [w:] Uwodzicielskie oblicza oświecenia. Szkice obyczajowe II, Katowice 2002, s. 70-81.

Schneidawind F.J.A., Leben Kaiser Josephs des Zweiten, Hamburg 1846.

Schnitzler J. H., Le premier voyage de l'empereur Joseph II à la cour de Marie-Antoinette, en 1777, „Revue des cours littéraires de la France et de l'étranger”, R. 3, 26 mai 1866, nr 26, s. 429-436.

Ségur P. de, Au couchant de la monarchie. Louis XVI et Turgot 1774-1776. Louis XVI et Necker 1776-1781, préf. de L. Pfaadt, Paris 2013.

Seibt F., Karol IV. Cesarz w Europie 1346-1378, tłum. C. Tarnogórski, Warszawa 1996.

Seksuologia. Zarys encyklopedyczny, red. K. Imieliński, Warszawa 1985.

Vincent B., Louis XVI, Paris 2006.

Weissensteiner F., Habsburgowie, tłum. B. i D. Lulińscy, Warszawa 2011.

Wyrobisz A., Żotnierze, weterani, inwalidzi wojenni - nowy problem spoleczny w miastach europejskich XVI-XVIII w. [w:] Wojsko. Społeczeństwo. Historia, Prace ofiarowane Profesorowi Mieczysławowi Wrzoskowi w sześćdziesiąta piata rocznice Jego urodzin, red. W. Fedorowicz, J. Snopko, Białystok 1995, s. 91-96.

Zweig S., Maria Antonina, tłum. Z. Petersowa, Katowice 1984. 